\title{
A Preliminary Evaluation of Heterotrophic Utilisation of a Labelled Algal Extract in a Subtidal Reef Environment
}

\author{
M. H. Schleyer \\ Oceanographic Research Institute, P.O. Box 10712, Marine Parade, Durban, 4056, South Africa
}

\begin{abstract}
An attempt was made to quantify microbial heterotrophy using a labelled algal organic extract (DO ${ }^{14} \mathrm{C}$ ) as a tracer. The heterotrophic potential technique was used and values obtained for $V_{\max } T$ and $K+S$ in parallel experiments were 13.2-72.6 $\mu \mathrm{g} \mathrm{C} \mathrm{I}^{-1} \mathrm{~h}^{-1}, 14.5-82.3 \mathrm{~h}$ and $604.0-4024.7 \mu \mathrm{g} \mathrm{C}^{-1}$ respectively for DO ${ }^{14} \mathrm{C}$ uptake, and $0.1-2.9 \mu \mathrm{g} 1^{-1} \mathrm{~h}^{-1}, 3.2-41.8 \mathrm{~h}$ and $1.3-48.2 \mu \mathrm{g} \mathrm{l}^{-1}$ for D- [U- $\left.{ }^{14} \mathrm{C}\right]$ glucose uptake. Greater growth yields (i.e. a lower \% label respired) were measured for DO ${ }^{14} \mathrm{C}$ than glucose. Production figures of $34.9-780.1 \mathrm{mg} \mathrm{C} \mathrm{m}^{-3} \mathrm{~h}^{-1}$ were obtained by relating the proportional uptake of tracer quantities of $\mathrm{DO}^{14} \mathrm{C}$ to the $\mathrm{DOC}$ in the seawater and these were much greater than increases in biomass established from acridine orange direct counts $\left(0.25-2.81 \mathrm{mg} \mathrm{C} \mathrm{m}{ }^{-3} \mathrm{~h}^{-1} \mathrm{cf}\right.$. related DO ${ }^{14} \mathrm{C}$ figures of $\left.34.9-369.5 \mathrm{mg} \mathrm{C} \mathrm{m}^{-3} \mathrm{~h}^{-1}\right)$. However, it appears that direct counts do not adequately reflect growth, and microbial assimilation of the $\mathrm{DO}^{14} \mathrm{C}$ conversely overestimates consumption of environmental DOC since this contains an unknown proportion of organics resistant to microbial degradation $(\mathrm{K}+\mathrm{S}$ derived from the heterotrophic potential technique $<$ directly measured $S$ as DOC). On evaluation of the results, the heterotrophic potential technique applied to $\mathrm{DO}^{14} \mathrm{C}$ uptake appears to provide a realistic estimate of microbial production.
\end{abstract}

\section{INTRODUCTION}

One of the most widely used methods of determining microbial heterotrophic activity in the aquatic environment to date has been the measurement of the uptake of labelled organic substrates such as glucose, acetate and dissolved free amino acids (DFAA) using the technique of Hobbie and Crawford (1969). At a range of low concentrations, assuming uptake of the labelled substrate follows enzyme kinetics, Wright and Hobbie $(1965,1966)$ derived the following equation:

$$
\frac{C \mu \mathrm{t}}{C}=\frac{(K+S)}{V_{\max }}+\frac{A}{V_{\max }}
$$

where $C=\mathrm{cpm}$ of $\mathrm{l} \mu \mathrm{Ci}$ of labelled substrate; $\mu=\mu \mathrm{Ci}$ label added; $c=c p m$ of labelled substrate assimilated; $t=$ time; $K=$ Michaelis-Menten transport constant; $S=$ naturally occurring concentration of the substrate under study; $A=$ concentration of added substrate; $V_{\max }=$ theoretical maximum rate of uptake of substrate when all uptake sites are occupied.

When $\frac{C \mu \mathrm{t}}{C}$ is plotted as the ordinate against $\mathrm{A}$, a straight line graph results with a slope of $\frac{1}{V_{\max }}$ and with intercepts on the abscissa and ordinate respectively of
$-(K+S)$ and the turnover time ( $T)$ of the substrate (Fig. 3). The results so obtained provide only an index of the activity of the microbes in taking up the substrate in question and, since $S$ is generally unknown, the equation cannot be solved for $K$. To overcome this problem Hobbie and Wright (1965) devised a bioassay for naturally occurring glucose and Crawford et al. (1974) analysed the DFAA using ion exchange chromatography, enabling the full equation to be solved. However, these workers detected competitive inhibition in the uptake of some combinations of simple sugars ad some DFAA of similar structure; other DFAA exhibited enhanced uptake. Although some of these experiments were performed at higher than natural concentrations, the results indicate fairly specific enzyme uptake systems and they do not reflect total organic uptake (see also Hobbie and Rublee, 1977). Thus the method, which has been developed from a technique originated by Parsons and Strickland (1962), provides only a good comparative index of productivity referred to as the heterotrophic potential by many of the authors cited thus far.

If it were feasible to provide a natural microbial population with a labelled complex substrate identical in constitution to the environmental substrate, it 
should be possible to perform uptake experiments measuring consumption (and ultimately growth) according to the equation of Wright and Hobbie (1966):

$$
v_{(S+A)}=\frac{C(S+A)}{C \mu \mathrm{t}}
$$

If $S$ is known and $A$ is added in tracer quantities (i. e., $A$ $\ll S$;

$$
v_{S}=c S / C \mu \mathrm{t}
$$

$v_{S}$ being the actual rate of uptake in nature. Such a 'perfect' tracer would vary in composition according to the origin of the natural substrate and could be difficult to produce in some instances. Wiebe and Smith (1977) proposed that excreted organic matter obtained from phytoplankton cultured in a medium largely of labelled inorganic carbon would provide a realistic tracer of high specific activity for estimation of bacterial production in oceanic systems. Using differential filtration techniques; Larsson and Hagström (1979) traced ${ }^{14} \mathrm{C}$ (as $\mathrm{NaH}^{14} \mathrm{CO}_{3}$ ) through phytoplanktonic fixation into $\mathrm{DO}^{14} \mathrm{C}$ exudate with subsequent assimilation of the latter by bacteria, providing an estimate of bacterial production from this source. Both approaches are suitable in systems in which bacterial heterotrophy is largely dependent on algal excretion as a nutrient source.

However, the present study was performed on water samples collected adjacent to a subtidal surf-washed reef off the Natal coast at Durban. Primary production on the reef and in the surrounding water column is low and the major input for filter feeders which predominate on the reef is from rapid physical breakdown of allochthonous seaweed and terrestrial macrophytic debris which accumulates adjacent to it (Berry, 1979; Schleyer, 1979 and in prep.). Soluble components rapidly leach out of the debris which is soon broken by surf action into fine particles. Since free bacteria comprise the greatest microbial fraction $(\sim 80 \%)$ and account for most of the heterotrophic potential ( $90 \%)$ on the reef (Schleyer, 1979 and in prep.), this dissolved organic component must provide the free bacteria with a rich food source. In reviewing the ecological role of marine macrophytes, Mann (1972) concluded that over $90 \%$ of their global production enters the detrital food chain as dissolved and particulate organic matter in this fashion.

In the present case a uniformly labelled, dissolved organic algal extract $\left(\mathrm{DO}^{14} \mathrm{C}\right)$ would provide a good tracer to study carbon flux through the system. This would result in heterotrophic potential measurements which might approximate microbial consumption, with values for parameters such as $K$ and $T$ which would be effective values for the environment because of inherent inhibitory effects of natural substrates (Hobbie and Rublee, 1977). Labelling a suitable seaweed with subsequent $\mathrm{DO}^{14} \mathrm{C}$ extraction would be ideal for this purpose provided labelling was uniform, but unequal growth between meristematic regions and older tissue would preclude this and a unicellular algal culture was used instead.

\section{METHODS}

\section{Production of Chlorella Organic Extract}

A saline-tolerant Chlorella culture was obtained from an outdoor tilapia monoculture system and $100 \mathrm{ml}$

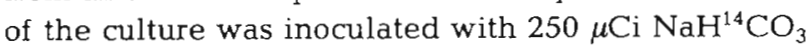
and incubated at ambient temperature in a boro-silicate bottle for two light and dark cycles (11L:13D) at 2000 lux. Assuming a generation time of $24 \mathrm{~h}$ for Chlorella (Lorenzen and Hesse, 1974) two generations of the culture were exposed to the ${ }^{14} \mathrm{C}$ over the incubation period, allowing uniform penetration by the label. After incubation the Chlorella were centrifuged and the peliet was reconstituted in a small quantity of sterile filtered seawater. To it was added the residual particulate fraction from the incubation medium which was collected on a $0.2 \mu \mathrm{m}$ pore size polycarbonate membrane filter and carefully removed with a clean razor blade by gently scraping it off after placing the filter on a flat sheet of clean glass. This procedure appeared to be successful since the filters used are flat and non-porous (Nuclepore Corp., Pleasanton, California 94566, USA) and collect particulate matter only on their surface unlike cellulosic membranes in which some filtrate is lost in the filter matrix. Excreted $\mathrm{DO}^{14} \mathrm{C}$ left in the medium was extracted by successively passing it through a SEP-PAK $\mathrm{C}_{18}$ chromatographic cartridge (Waters Associates Inc., Milford, Massachusetts 01757, USA) and eluting the organics with a few millilitres of methanol. After repeating this process five times to ensure extraction of all the $\mathrm{DO}^{14} \mathrm{C}$ the methanol was evaporated in a hot water bath and the dissolved organic material was also added to the reconstituted pellet. This was sonicated in an ice bath at 100-150W for 20 min using an Ultrasonic SP914 probe sonicator and then repeatedly frozen and thawed to achieve maximum disruption of the cellular components. Finally it was centrifuged at $1800 \mathrm{~g}$ for $30 \mathrm{~min}$ and remaining ${ }^{14} \mathrm{CO}_{2}$ was flushed of by bubbling ${ }^{12} \mathrm{CO}_{2}$ through the supernatant which was then membrane filtered $(0.2 \mu \mathrm{m}$ pore size) and frozen in a sterile container until use. Dissolved organic carbon (DOC) content of the resultant $\mathrm{DO}{ }^{14} \mathrm{C}$ and of experimental seawater samples was analysed using a Beckman Carbon Analyser. Radioactive counting was performed using a Packard Model 3380 liquid scintillation counter, fitted with automatic external standardisation and an Absolute Activity Analyser Model 544 for conversion of cpm 
to dpm. The specific activity of the $\mathrm{DO}^{14} \mathrm{C}$ was estab-

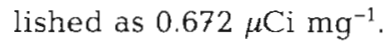

\section{Measurement of Heterotrophic Potential}

The method of Hobbie and Crawford (1969) was employed with a few modifications to measure heterotrophic potential using tracer quantities of $\mathrm{D}-\left[\mathrm{U}-{ }^{14} \mathrm{C}\right]$ glucose and the $\mathrm{DO}^{14} \mathrm{C}$ in parallel experiments. $25 \mathrm{ml}$ seawater samples in sealed $125 \mathrm{ml}$ erlenmeyer flasks were inoculated to final concentrations of $0.656-3.282$ mg $\mathrm{C}^{-1} \mathrm{DO}^{14} \mathrm{C}$ or $0.645-3.226 \mu \mathrm{g} \mathrm{l}^{-1}$ glucose. These were incubated for $1 \mathrm{~h}$ in the dark at sea temperature and the assimilated particulate and respired fractions of ${ }^{14} \mathrm{C}$ were then separately collected for counting. Sterile filtered seawater samples with added labelled substrate were used as controls for background counts and to monitor sterility of the substrates. At the end of incubation, addition of $1 \mathrm{ml}$ of $2 \mathrm{~N} \mathrm{H}_{2} \mathrm{SO}_{4}$ to stop biological activity and release respired (in controls residual) ${ }^{14} \mathrm{CO}_{2}$ prior to filtration caused precipitation of a component of the $\mathrm{DO}^{14} \mathrm{C}$. The result was that the highest filtrate counts were found in the controls in which no $\mathrm{DO}^{14} \mathrm{C}$ was assimilated by bacteria. Therefore, filtration was performed immediately after incubation without fixation or, when large numbers of samples were handled, biological activity was effectively reduced by sample dilution with sterile filtered seawater. In this way, release of assimilated label from the particulate fraction which is another adverse effect of chemical fixation or acid treatment (Griffiths et al., 1974; Hobbie and Rublee, 1977), was avoided and samples were duplicated for separate collection and measurement of ${ }^{14} \mathrm{CO}_{2}$.

If ${ }^{14} \mathrm{CO}_{2}$ had been used in the formation of $\mathrm{Ca}^{14} \mathrm{CO}_{3}$ by organisms such as coccolithophores which often produce mineralised body scales (coccoliths), it would not have been released by $\mathrm{H}_{2} \mathrm{SO}_{4}$ which coats $\mathrm{Ca}^{14} \mathrm{CO}_{3}$ particles with $\mathrm{CaSO}_{4}$ and protects them from further acid attack, in which case the samples should rather be acidified with $\mathrm{H}_{3} \mathrm{PO}_{4}$. Enrichment cultures of the ORI Reef samples revealed that organisms such as prymnesiophyte microflagellates were best represented by genera with unmineralised body scales but the natural populations can include large numbers of mineralised species (Pienaar, pers. comm.). However, incorporation of ${ }^{14} \mathrm{CO}_{2}$ as $\mathrm{Ca}^{14} \mathrm{CO}_{3}$ by forms of these autotrophs with mineralised coccoliths is a light-dependent process (Pienaar, 1976; see also Ariovich and Pienaar, 1979) and is unlikely to have occurred under the dark experimental conditions. Thus $\mathrm{H}_{2} \mathrm{SO}_{4}$ was considered suitable for the purpose intended.

In the original method of Hobbie and Crawford (1969) the ${ }^{14} \mathrm{CO}_{2}$ was collected and bound as carbamine by introduction of a small amount of phenylethyl- amine into the closed experimental system on chromatographic paper. In the present work this reaction was found to be so strongly exothermic that the phenylethylamine and carbamine fumed and were lost as they recondensed on the cool glass sides of the erlenmeyer flask. The efficiency of ${ }^{14} \mathrm{CO}_{2}$ collection was improved by introducing $100 \mu \mathrm{l}$ phenylethylamine into a small capless vial suspended in a wire cradle and the efficiency of this was tested by collection of the labelled gas released by acid from small amounts of $\mathrm{NaH}^{14} \mathrm{CO}_{3}$. With this modification most of the condensation occurs on the sides of the vial and is easily rinsed with cocktail into a counting vial. Furthermore, any detrimental effects such as absorption of counts by the filter paper are avoided.

Another problem previously encountered in this method is the filtration error which is a background count in water retained by the membrane filter and adsorped directly onto it during filtration (Hobbie and Rublee, 1977). This error was reduced to a minimum by the use of very thin inert polycarbonate membranes (0.2 $\mu \mathrm{m}$ pore size Nuclepore filters) which retain little water. After filtration the filter and labelled filtrate were digested by $100 \mu \mathrm{l}$ phenylethylamine in a scintillation vial and Instagel (Packard Instruments, Downers Grove, Illinois 60515, USA) was then added to the samples before counting.

\section{Measuring Biomass from Direct Counting Techniques}

In ancillary experiments, acridine orange direct counts (AODC) were performed on seawater using the technique of Hobbie et al. (1977) at the start and end of incubation of separate subsamples with $0.656 \mathrm{mg} \mathrm{C}$ $\mathrm{I}^{-1} \mathrm{DO}^{14} \mathrm{C}$ in an attempt to relate heterotrophic uptake of the label with natural bacterial proliferation. The increase in number was converted to a change in volume of the bacteria and hence to an increase in biomass. Mean values of bacterial volumes from SEM measurements of the bacteria were used in these calculations. Details of this analysis are reported elsewhere with comprehensive work which compares primary and detrital input into the system under study and the heterotrophic role of the different size fractions of the nannoplankton (Schleyer, 1979 and in prep.).

In a single experiment, 31 of seawater were incubated in a sterile $5 \mathrm{l}$ erlenmeyer flask in the dark for eight hours. The neck of the flask was closed with a sterile cotton wool plug to allow gas exchange and surf action was simulated as far as possible by vigorous stirring with a magnetic stirrer. Subsamples were periodically removed for $\mathrm{AODC}$ and measurement of heterotrophic uptake of $0.656 \mathrm{mg} \mathrm{C}^{-1} \mathrm{DO}^{14} \mathrm{C}$ to monitor long-term changes in heterotrophic activity and biomass. 


\section{RESULTS}

Despite the fact that the $\mathrm{DO}^{14} \mathrm{C}$ was a complex mixture of compounds, uptake of this substrate was perfectly linear over the incubation period (Fig. 1). Double reciprocal plots of uptake versus substrate concentration were also linear, displaying typical enzyme saturation kinetics (Fig. 2). Lineweaver-Burk plots (Fig. 3) of the data according to Equation (1) provided the results in Table 1.

The percentage respired of the total ${ }^{14} \mathrm{C}$ glucose and $\mathrm{DO}^{14} \mathrm{C}$ taken up differed significantly. In the case of glucose a mean respiration value of $22 \%$ of the total uptake was obtained from the present study and a previous year's fortnightly results (Schleyer, 1979 and in prep.). Respiration of the $\mathrm{DO}^{14} \mathrm{C}$ was considerably lower and fairly consistent at a mean of $1.5 \%$ of the total uptake.

Measurements of DOC in the seawater, which were assumed to comprise $S$, varied between 12.8 and 16.5 $\mathrm{mg} \mathrm{C} \mathrm{l}^{-1}$. When these measurements were substituted for $\mathrm{S}$ and the data on the uptake of $0.656 \mathrm{mg} \mathrm{Cl}^{-1}$ $\mathrm{DO}^{14} \mathrm{C}$ were substituted for $c / C \mu$ t in Equation (3), $v_{S}$ values were obtained. These are tabulated with respective biomass changes in Table 2 .

In the 8-h experiment, bacterial proliferation (established by AODC) was initially more rapid but gradually lost impetus, while heterotrophic uptake of subsamples provided with $\mathrm{DO}^{14} \mathrm{C}$ increased linearly with time (Fig. 4). Slight pleomorphic changes occurred as the predominant small cocci gradually increased in size and a small increase in the number of rods and

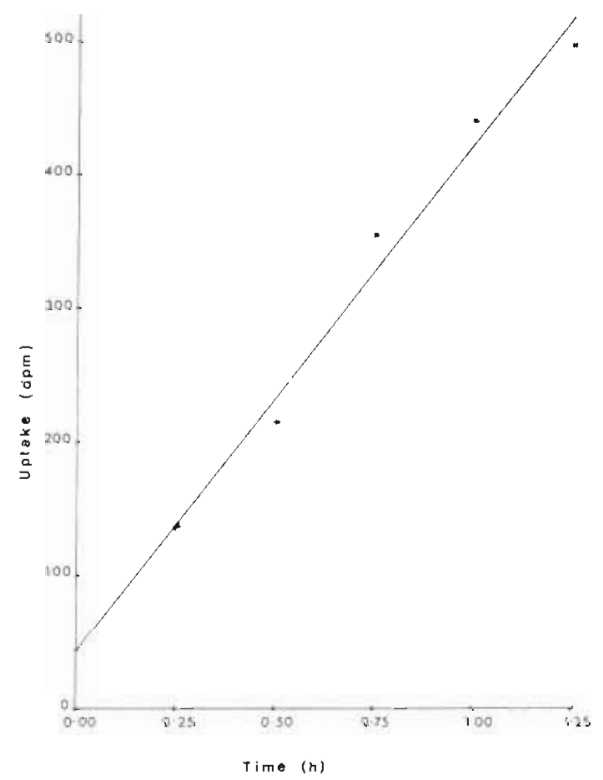

Fig. 1. Linearity of uptake of $\mathrm{DO}^{14} \mathrm{C}$ over the incubation period commas was observed. More bacteria were attached to particles at the end of the experiment $(12 \%$ of the AODC) than at the start ( $4 \%$ of the AODC). These changes were cumulative over the eight hour period and could not be detected in the short-term incubations.

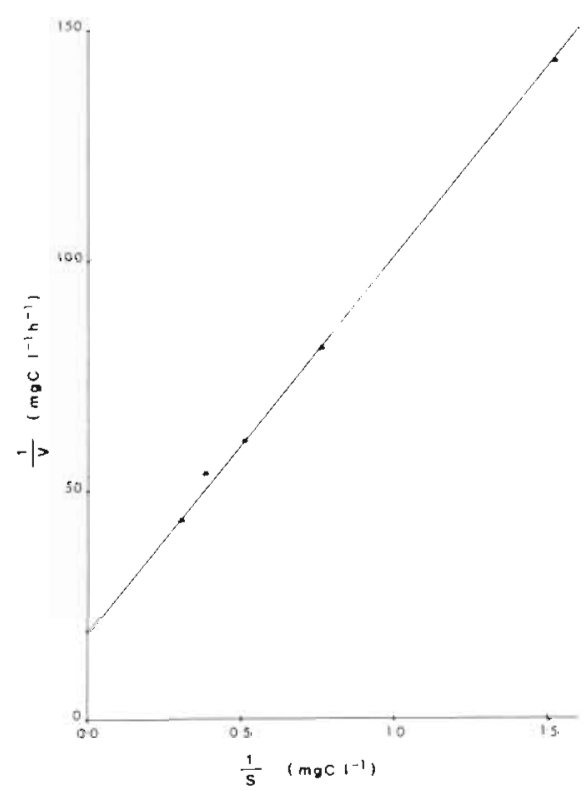

Fig. 2. Typical double reciprocal plot of $\mathrm{DO}^{14} \mathrm{C}$ concentration versus uptake; enzyme saturation kinetics indicated by linearity of the graph

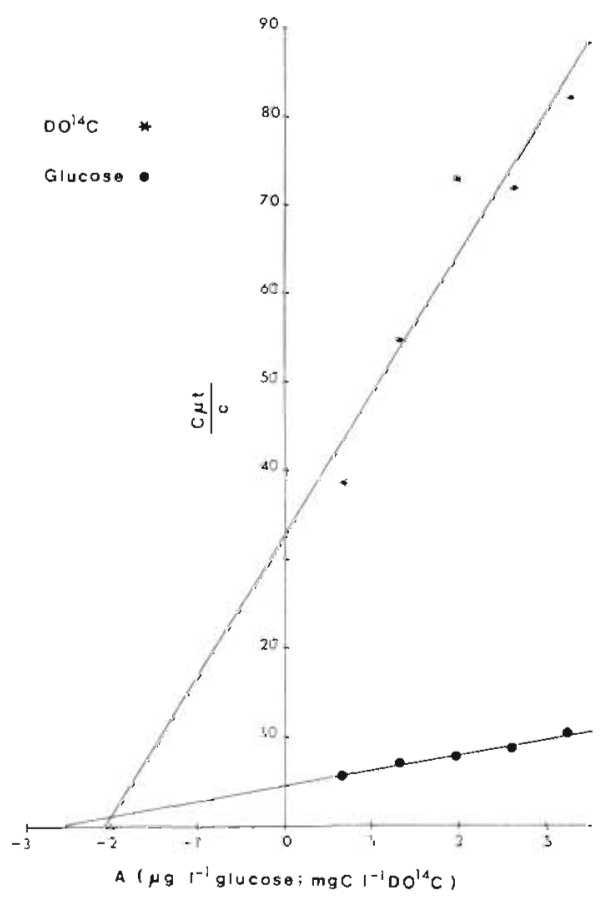

Fig. 3. Typical Lineweaver-Burk plot of $\mathrm{DO}^{14} \mathrm{C}$ and labelled glucose uptake 
Table 1. Results of Lineweaver-Burk plots of $\mathrm{DO}^{14} \mathrm{C}$ and glucose uptake with DOC measurements of the seawater (hypothetical $S$ ). Using the $F$ ratio test, all results proved significant at the $95 \%$ level with the exception of a single sample marked + ; those marked " were significant as well as predictive, the latter being defined as an $F$ ratio greater than four times the critical $F$ value

\begin{tabular}{|c|c|c|c|c|c|c|c|}
\hline \multirow[t]{2}{*}{ Sample } & \multicolumn{3}{|c|}{$\mathrm{DO}^{14} \mathrm{C}$} & \multicolumn{3}{|c|}{ Glucose } & \multirow{2}{*}{$\begin{array}{c}\text { DOC } \\
S^{\prime} \\
\left(\operatorname{mg} C^{C} 1^{-1}\right)\end{array}$} \\
\hline & $\left(\mu \mathrm{g} \mathrm{C} \mathrm{^{-1 } h ^ { - 1 } )}\right.$ & $\begin{array}{c}T \\
\text { (h) }\end{array}$ & $\begin{array}{c}K+S \\
\left(\mu \mathrm{g} \mathrm{C} l^{-1}\right)\end{array}$ & $\underset{\left(\mu \mathrm{g} \mathrm{l^{-1 }} \mathrm{h}^{-1}\right)}{V_{\max }}$ & $\begin{array}{c}T \\
(\mathrm{~h})\end{array}$ & $\begin{array}{c}K+S \\
\left(\mu \mathrm{g} \mathrm{l}^{-1}\right)\end{array}$ & \\
\hline 1 & $72.6^{\circ}$ & $14.5^{\circ}$ & $1049.7^{\circ}$ & 2.9 & 3.2 & 9.2 & 16.2 \\
\hline 2 & $13.2^{*}$ & $61.2^{\circ}$ & $807.6^{\circ}$ & 0.1 & 10.6 & 1.3 & 12.8 \\
\hline 3 & $48.9^{\circ}$ & $82.3^{\circ}$ & $4024.7^{\circ}$ & $1.2+$ & $41.8+$ & $48.2+$ & 16.2 \\
\hline 4 & 63.1 & 32.8 & 2066.6 & $0.6^{*}$ & $4.6^{\circ}$ & $2.6^{\circ}$ & 13.5 \\
\hline 5 & 40.2 & 15.0 & 604.0 & 1.4 & 4.0 & 5.7 & 16.5 \\
\hline
\end{tabular}

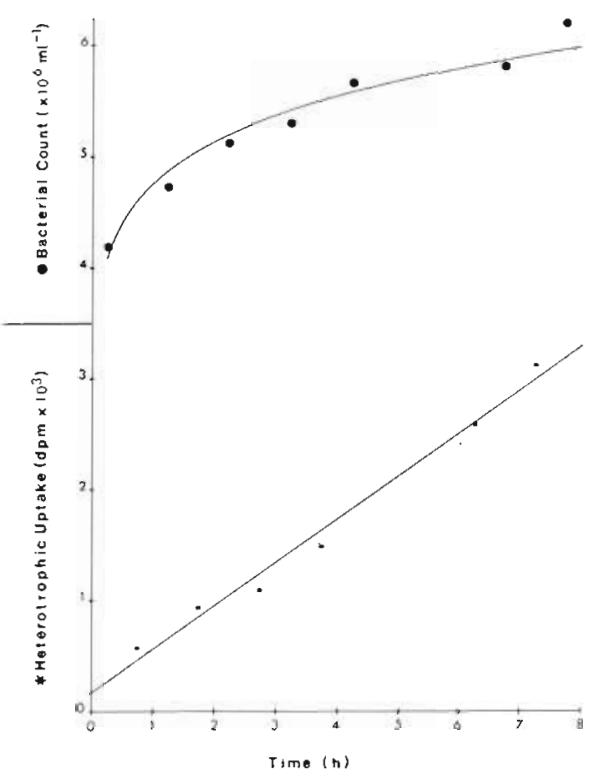

Fig. 4. Increase in bacterial number and heterotrophic uptake of $\mathrm{DO}^{14} \mathrm{C}$ in subsamples in the 8-h experiment described in the text

\section{DISCUSSION}

Using the heterotrophic potential technique, $\mathrm{DO}^{14} \mathrm{C}$ uptake was considerably greater than ${ }^{14} \mathrm{C}$ glucose uptake (Table 1), but the data were too few to determine whether there was a mathematical relationship between the rates of uptake of the two labels. The value of $(K+S)$ was smaller than the quantity of naturally occurring DOC which had thus incorrectly been assumed to comprise $S$. In his review on dissolved organics in aquatic environments, Jørgensen (1976) considered most of the DOC to be highly resistant to microbial degradation with only a small fraction consisting of easily assimilable substances such as amino acids, carbohydrates and fatty acids. In a detritus subsidised neritic environment such as the one under study, the proportion of assimilable organics in the
Table 2. $v_{S}$ values and related changes in bacterial biomass $(\triangle B)$ calculated from AODC according to Sorokin and Kadota (1972). Bacterial biomass at the start of each experiment is also listed $\left(B_{0}\right) . V_{\max }$ values of $\mathrm{DO}^{14} \mathrm{C}$ uptake are included for comparison

\begin{tabular}{|ccccc|}
\hline Sample & $V_{\max }$ & $\begin{array}{c}\mathrm{v}_{\mathrm{S}} \\
\left(\mathrm{mg} \mathrm{C} \mathrm{m}^{-3} \mathrm{~h}^{-1}\right)\end{array}$ & $\triangle B$ & $\begin{array}{c}B_{\mathrm{o}} \\
\left(\mathrm{mg} \mathrm{C} \mathrm{m}^{-3}\right)\end{array}$ \\
\hline 1 & 72.6 & 780.1 & - & - \\
2 & 13.2 & 120.5 & - & - \\
3 & 48.9 & 177.4 & - & - \\
4 & 63.1 & 366.9 & - & - \\
5 & 40.2 & 676.0 & - & - \\
6 & - & 369.5 & 2.81 & 21.59 \\
7 & - & 108.5 & 0.73 & 9.05 \\
8 & - & 123.2 & 0.25 & 10.11 \\
9 & - & 81.2 & 0.27 & 9.52 \\
10 & - & 165.5 & 1.07 & 9.69 \\
11 & - & 173.4 & 0.94 & 9.39 \\
12 & - & 34.9 & 0.35 & 9.04 \\
& & & & \\
\hline
\end{tabular}

DOC will be greater than in many of the environments reviewed by Jørgensen, but a proportion of organics resistant to degradation will still be present. Only compositional analysis of the $\mathrm{DO}^{14} \mathrm{C}$ and $\mathrm{DOC}$ would reveal the similarity of the labelled substrate to the assimilable fraction of the latter which comprises $S$.

Since the true value of $S$ is unknown it cannot be assumed that $A \ll S$ or $A \approx \mathrm{O}$ and the substitution of DOC for $S$ in Equation (3) has led to overestimation of $v_{S}$ (Table 2). Solution of Equation (2) substituting $(K+S)$ for $S$ yields $V_{K+S+A}$ values slightly higher than respective $V_{\max }$ values due to the added effect of $K$. If the $\mathrm{DO}^{14} \mathrm{C}$ is in fact representative of the environmental substrate (the assimilable component of the DOC), this indicates that values for $V_{\max }$ are a realistic measure of microbial heterotrophic consumption in the environment.

Uniformity in labelling is a parameter which would affect the usefulness of the $\mathrm{DO}^{14} \mathrm{C}$ in this work and this would be influenced more by duration of incubation than concentration of ${ }^{14} \mathrm{C}$ in the preparation medium. The long incubation used in its preparation should 
have given uniform labelling and the only problem in its production was a low ${ }^{14} \mathrm{C}:{ }^{12} \mathrm{C}$ ratio which resulted in $\mathrm{DO}^{14} \mathrm{C}$ of fairly low specific activity. This necessitated relatively high inoculation concentrations of the $\mathrm{DO}^{14} \mathrm{C}$ and future work will include the high specific activity labelling technique of Wiebe and Smith (1977).

${ }^{14} \mathrm{C}$ glucose was more extensively used as an energy source with a larger percentage of the uptake being respired than was the case with $\mathrm{DO}^{14} \mathrm{C}$. According to Williams (1970), the higher growth yield (lower percentage respired) obtained with $\mathrm{DO}^{14} \mathrm{C}$ would indicate that the main flow of this substrate went into metabolic pathways other than respiration during the incubation period. He furthermore discusses the lack of evidence for a time lag in the oxidation of more complex substrates by natural bacterial populations, which would cause a drop in the growth yield over longer incubation periods. This high growth yield supports the assumption that labelling of the $\mathrm{DO}^{14} \mathrm{C}$ was uniform and not concentrated in simple cell products such as hexoses which would have been rapidly metabolised and respired.

Since respiration of this substrate was so low, values for $V_{\max }$ represented a turnover rate $(P / B)$ of the biomass (Table 2) of approximately 1-7 times per hour if the little-understood release of extracellular products by bacteria (Allen, 1977; Wangersky, 1978) is ignored. The turnover rate would be less if only labelled substrate incorporated into the cells was taken into account and the extracellular releases could be excluded.

At the higher concentrations of $\mathrm{DO}^{14} \mathrm{C}$ used in the heterotrophic potential technique it is possible that $A \geq S$ and at such non-tracer levels Wright and Hobbie (1966) found that algae display passive uptake by diffusion. In reviewing this problem, Hobbie and Rublee (1977) felt that tracer and nontracer experiments give similar results provided that it is established that the grossly different uptake mechanisms of algae do not become evident. Although micro-flagellates are predominant in the phytoplankton (Schleyer, 1979), differential filtration and antibiotic inhibition studies indicated that the greatest proportion of $\mathrm{DO}^{14} \mathrm{C}$ uptake was performed by bacteria (Schleyer, in prep.). In fact the small proportion of $\mathrm{DO}^{14} \mathrm{C}$ apparently consumed by flagellates may have been ingested after incorporation in the bacteria on which Haas and Webb (1979) found some non-pigmented forms feed.

The increase in biomass calculated from AODC was far less than one would expect from measurements of $\mathrm{V}_{\max }$ and the overestimates of $v_{S}$ (Table 2). In the 8-h experiment growth, measured as an increase in bacterial number (Fig. 4), was observed to be accompanied by a gradual increase in size at least of the predomi- nant small cocci. Slight pleomorphic changes also occurred and attachment mechanisms were presumably produced as more bacteria adhered to particles. Relative to their proliferation the bacteria became more active in the uptake of $\mathrm{DO}^{14} \mathrm{C}$ (Fig. 4) and it appears that actual growth was underestimated when measured only as a proliferation under experimental conditions. In support of this Paerl (1978) found changes in direct counts accounted for as little as under $5 \%$ of the heterotrophic carbon uptake by free and attached freshwater bacteria, much of this being laid down as extracellular material. However, the initial biomass values on the reef (Table 2) were comparable to previous estimates (Schleyer, 1979) and were used in the calculation of the approximate turnover rates given above.

Andrews and Williams (1971) measured the oxidation rate of different substrates to assess bacterial activity in the English Channel. They concluded from their work that bacterial activity and substrate concentrations are interrelated such that bacteria control the latter and 'only under unusual circumstances do high substrate levels occur'. In a study in which they measured bacterial respiratory response to DOC enrichment, Sayler and Gilmour (1978) found that this interrelationship was direct and linear. A strong correlation similarly exists between primary production and bacterial activity (Hobbie and Rublee, 1977), since the former is also associated with DOC excretion which is consumed by bacteria (Hobbie and Rublee, 1977; Wiebe and Smith, 1977; Larsson and Hagström, 1979). This reveals that marine bacteria are sensitively adapted to their environment in their short-term enzyme control mechanisms. It is likely that if the $\mathrm{DO}^{14} \mathrm{C}$ used in the present study closely simulates the assimilable component of the natural DOC, its rate of uptake could throw considerable light on carbon flux through this detritus-based system using the heterotrophic potential technique. Further work on uniformity of labelling and the composition of the $\mathrm{DO}^{14} \mathrm{C}$ and $\mathrm{DOC}$ will enable refinement of the method to quantify bacterial heterotrophic consumption in absolute terms rather than as an index. Once perfected, the method could be adapted to other detrital systems.

Acknowledgements. I gratefully acknowledge financial support for this work by the South African National Committee for Oceanographic Research and the South African Association for Marine Biological Research. I am also grateful to Dr N. W. Pammenter and Mrs. B. Huckett for helpful discussion during the work. 


\section{LITERATURE CITED}

Allen, H. L. (1977). Experimental studies of dissolved organic matter in a soft-water lake. In: Cairns, J. (ed.) Aquatic microbial communities. Garland Publishing, New York, pp. $477-527$

Andrews, P., Williams, P. J. Le B. (1971). Heterotrophic utilization of dissolved organic compounds in the sea. III. Measurement of the oxidation rates and concentrations of glucose and amino acids in sea water. J. mar. biol. Ass. U. K. 51: 111-125

Ariovich, D., Pienaar, R. N. (1979). The role of light in the incorporation and utilization of $\mathrm{Ca}^{++}$ions by Hymenomonas carterae (Braarud et Fagerl.) Braarud (Prymnesiophyceae). Br. phycol. J. 14: 17-24

Berry, P. F., Hanekom, P., Joubert, C., Joubert, I., Schleyer, M., van der Elst, R. (1979). Preliminary account of the biomass and major energy pathways through a Natal nearshore reef community. S. Afr. J. Sci. 75: 565

Crawford, C. C., Hobbie, J. E., Webb, K. L. (1974). The utilization of dissolved free amino acids by estuarine microorganisms. Ecology 55: 551-563

Griffiths, R. P., Hanus, F. J., Morita, R. Y. (1974). The effects of various water sample treatments on the apparent uptake of glutamic acid by natural marine microbial populations. Can. J. Microbiol. 20: 1260-1266

Haas, L. W., Webb, K. L. (1979). Nutritional mode of several non-pigmented microflagellates from the York River estuary, Virginia. J. exp. mar. Biol. Ecol. 39: 125-134

Hobbie, J. E., Crawford, C. C. (1969). Respiration corrections for bacterial uptake of dissolved organic compounds in natural waters. Limnol. Oceanogr. 14: 528-532

Hobbie, J. E., Daley, R. F., Jasper, S. (1977). Use of Nuclepore filters for counting bacteria by fluoresence microscopy. Appl. envir. Microbiol. 33: 1225-1228

Hobbie, J. E., Rublee, P. (1977). Radioisotope studies of heterotrophic bacteria in aquatic ecosystems. In: Cairns, J. (ed.) Aquatic microbial communities. Garland Publishing, New York, pp. 441-476

Hobbie, J. E., Wright, R. T. (1965). Bioassay with bacterial uptake kinetics: glucose in freshwater. Limnol. Oceanogr. 10; $471-474$

Jørgensen, C. B. (1976). August Pütter, August Krogh, and modern ideas on the use of dissolved organic matter in aquatic environments. Biol. Rev. 51: 291-328

Larsson, U., Hagström, A. (1979). Phytoplankton exudate release as an energy source for the growth of pelagic bacteria. Mar. Biol. 52: 199-206
Lorenzen, H., Hesse, M. (1974). Synchronous cultures. In: Stewart, W. D. P. (ed.) Algal physiology and biochemistry. Blackwell Scientific Publications, London, pp. 894-908

Mann, K. (1972). Macrophyte production and detritus food chains in coastal waters. Memorie Ist. ital. Idrobiol. 29: 353-383

Paerl, H. W. (1978). Microbial organic carbon recovery in aquatic ecosystems. Limnol. Oceanogr. 23: 927-935

Parsons, T. R., Strickland, J. D. H. (1962). On the production of particulate organic carbon by heterotrophic processes in sea water. Deep Sea Res. 8: 211-222

Pienaar, R. N. (1976). The rhythmic production of body covering components in the Haptophycean flagellate Hymenomonas carterae. In: Watabe, N., Wilbur, K. M. (eds) The mechanisms of mineralization in the invertebrates and plants. University of South Carolina Press for the Belle W. Baruch Institue for Marine Biology and Coastal Research, Columbia, pp. 203-229

Sayler, G. S., Gilmour, C. M. (1978). Heterotrophic utilization of organic carbon in aquatic environments. J. Environ. Qual. 7: 385-391

Schleyer, M. H. (1979). Preliminary results of a comparative study of the roles of bacteria and phytoplankton in the littoral waters of Natal. S. Afr. J. Sci. 75: 566

Schleyer, M. H. (In prep.). A comparative study of the roles of phytoplankton and bacteria with associated detritus in a subtidal reef ecosystem of Natal

Sorokin, Y. I., Kadota, H. (eds) (1972). Techniques for the assessment of microbial production and decomposition in fresh waters, Blackwell Scientific Publications, Oxford

Wangersky, P. J. (1978). Production of dissolved organic matter. In: Kinne, O. (ed.) Marine Ecology, Vol. IV, Dynamics. Wiley, Chichester, pp. 115-220

Wiebe, W. J., Smith, D. F. (1977). ${ }^{14} \mathrm{C}$-Labeling of the compounds excreted by phytoplankton for employment as a realistic tracer in secondary productivity measurements. Microbial ecology 4: 1-8

Williams, P. J. Le B. (1970). Heterotrophic utilization of dissolved organic compounds in the sea. I. Size distribution of population and relationship between respiration and incorporation of growth substrates. J. mar. biol. Ass. U. K. 50: $859-870$

Wright, R. T., Hobbie, J. E. (1965). The uptake of organic solutes in lake water. Limnol. Oceanogr. 10: 22-28

Wright, R. T., Hobbie, J. E. (1966). Use of glucose and acetate by bacteria and algae in aquatic ecosystems. Ecology 47 : $449-464$ 